\section{EFFECT OF DRYING CONDITION ON DRYING RATE AND PHYSICOCHEMICAL OF MORINGA OLEIFERA LEAVES MILK POWDER}

\author{
Joko Waluyo*, Dewi Rachma Widowati, Jihan Nabillah \\ Chemical Engineering Department, Faculty of Engineering, \\ Universitas Sebelas Maret, Surakarta 57126 Indonesia
}

Article history

Received

7 June 2021

Received in revised form

27 August 2021

Accepted

2 September 2021

Published Online

20 October 2021

*Corresponding author jokowaluyo@staff.uns.ac.id

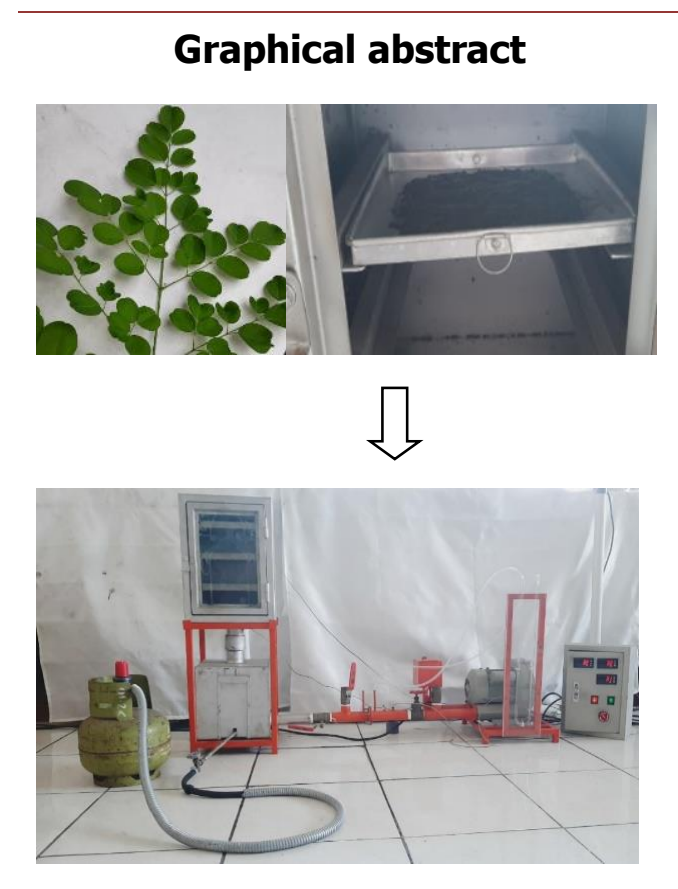

\begin{abstract}
People with animal protein allergies are not allowed to consume cow's milk. Moringa oleifera are rich in a number of nutrients such as protein, vitamins, calcium, iron, and micronutrients, and can be an alternative to substitute cow's milk. This study aimed to evaluate the influence of drying air temperature and air velocity on drying rate, drying kinetic and the physicochemical properties of moringa milk powder. The drying process was conducted using a tray dryer with a foam mate drying method. Moringa leaves and sesame seeds were crushed for 10 minutes using a blender. The mixture was filtered by filter paper and then mixed with dextrin and eggwhite as foaming agents of $20 \%$ and $15 \%$ weight, respectively. A baking sheet containing Moringa paste with a thickness of $5 \mathrm{~mm}$ was inserted into the tray dryer. The hot air at velocity variations of $0.2 \mathrm{~m} / \mathrm{s}$ and $0.3 \mathrm{~m} / \mathrm{s}$, and temperature variations of $90^{\circ} \mathrm{C}, 110^{\circ} \mathrm{C}$, and $130^{\circ} \mathrm{C}$ were applied to dry moringa paste. Lewi's model was used to determine the drying kinetic of moringa oleifera milk powder. The optimum drying process occurred at the temperature of $130^{\circ} \mathrm{C}$ and the air velocity of $0.2 \mathrm{~m} / \mathrm{s}$ with a critical time ( $t_{c}$ ) 20 minutes, the critical water content of the sample $\left(X_{c}\right) 2.304 \mathrm{~kg} \mathrm{H}_{2} \mathrm{O} / \mathrm{kg}$-drysolids, a constant drying rate $\left(R_{c}\right) 0.365 \mathrm{~kg} \mathrm{H}_{2} \mathrm{O} /$ minute. $\mathrm{cm}^{2}$, and drying kinetic constant (k) $0.0335 \mathrm{~min}^{-1}$. This study succeeded in producing powdered milk with the highest fat content of $14 \%$ while the protein content of $19.2 \%$.
\end{abstract}

Keywords: Drying rate, lewis models, milk powder, moringa oleifera, tray dryer

(C) 2021 Penerbit UTM Press. All rights reserved

\subsection{INTRODUCTION}

Energy and nutritional needs for a person can be fulfilled by formula milk intake. Milk naturally contains important nutrients, such as protein, calcium, magnesium, fat, phosphorus, and various vitamins, so that milk is an option for additional nutritional intake to fulfill the nutritional needs of the toddler to the elderly. However, in Indonesia, milk consumption is still relatively low compared to other countries. This is due to the high price of formula milk that can not be afforded by the poor [1].

People with animal proteins allergy are not allowed to consume cow's milk. Milk made from moringa leaves (Moringa oleifera) can be an alternative option to substitute cow's milk. Allergen in cow's milk protein is often found in various hypersensitivity reactions in children. Cow's milk protein consists of two fractions, namely casein and whey. The main allergens in cow's milk are distributed between the two fractions. In the 
whey fraction, the proteins that act as allergens are alpha-lactalbumin, beta-lactoglobulin, bovine serum albumin dan bovine immunoglobulins. On the other hand, the casein protein allergen consists of alphas!,

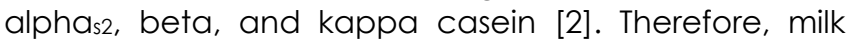
that comes from plant-based sources can be utilized as an alternative to cow's milk. In this study, we proposed plant-based milk powder from Moringa leaves.

Moringa (Moringa oleifera) is a tree whose leaves can be utilized as vegetables, foods and medicine. Several studies about moringa leaves that have shown to be beneficial in several chronic diseases, including cardiovascular disease, diabetes, hypertension and others [3], moringa leaves have been processed into an antioxidant instant drink [4], and moringa leaves could be a supplemented biscuits to enhance nutritional content [5]. Moringa is also called "The Miracle Tree" because of its nutritional value. Every 100 grams of dried moringa leaves contain protein that equals cow's milk, calcium 1.2 times more than cow's milk, vitamin A 1.6 times more than a carrot, and higher potassium and iron than banana and spinach [6]. Therefore, moringa leaves are very suitable to be utilized as a substitute for cow's milk. However, the fat content of Moringa leaves is low so that additional ingredients are needed. Sesame (Sesamum indicum L.) is grown and cultivated in tropical regions around the world for its edible seed. Sesame seed is one of the oldest oilseed crops known over 3000 years ago. The fat content of the seed is $56.6 \%$ so that is a potential additional ingredient for moringa milk [7]. A comparison of nutritional content between moringa leaves and other sources is presented in Table 1.

Table 1 A Comparison of Nutritional Content between Dried Moringa Leaves and other Sources $[6,7,8]$

\begin{tabular}{|c|c|c|c|c|}
\hline No & Parameters & $\begin{array}{c}\text { Dried } \\
\text { Moringa } \\
\text { Leaves }\end{array}$ & \multicolumn{2}{|c|}{ Comparison } \\
\hline 1 & $\begin{array}{l}\text { Protein } \\
(\mathrm{g} / 100 \mathrm{~g})\end{array}$ & 33.33 & $\begin{array}{l}\text { Cow's } \\
\text { milk }\end{array}$ & 33.33 \\
\hline 2 & $\begin{array}{l}\text { Fat } \\
(\mathrm{g} / 100 \mathrm{~g})\end{array}$ & $3.2-3.8$ & $\begin{array}{l}\text { Sesame } \\
\text { seed }\end{array}$ & 56.6 \\
\hline 3 & $\begin{array}{l}\text { Calcium } \\
(\mathrm{mg} / 100 \mathrm{~g})\end{array}$ & $1,449-1,665$ & $\begin{array}{l}\text { Cow's } \\
\text { milk }\end{array}$ & 1,292 \\
\hline 4 & $\begin{array}{l}\text { Potassium } \\
(\mathrm{mg} / 100 \mathrm{~g})\end{array}$ & $2,324-2,861$ & Banana & 358 \\
\hline 5 & $\begin{array}{l}\text { Iron } \\
\text { (mg/100 g) }\end{array}$ & $20.77-22.64$ & Spinach & 2.71 \\
\hline 6 & $\begin{array}{l}\text { Vitamin A } \\
(\mathrm{mg} / 100 \mathrm{~g})\end{array}$ & $61.9-62.4$ & Carrot & 38 \\
\hline
\end{tabular}

Food products such as milk, fruits, and vegetables have the highest water activity (aw) more than 0.95, while the minimum water activity for microorganisms to grow is 0.6-0.9. Due to the high water activity, the milk is very susceptible to microorganisms, which will shorten the shelf life of the milk. The growth of microorganisms can be prevented by reducing moisture content and water activity to a certain number, so that food can be stored for a long time [9]. Drying technology is a method for reducing moisture content in food. There are various ways of drying method can be applied to make moringa milk powder. Tray dryer is easier to operate rather than vacuum drying, faster drying time than fluidized bed or microwave oven, and is inexpensive drying method [10].

Tray drying process can decrease the moisture content of the sample under $10 \%$. This was proven by research carried out by Guda and Gadhe [11] that tray dryer decreased the moisture content of cocoa beans from $49.35 \%$ (w.b.) to $7.45 \%$ (w.b.) within 7 hours. In another study carried out by Naik et al., [12], Tray drying of tomato powder showed $5.51 \%$ moisture content. Thus, tray dryer is suitable for this study, which aims to determine the effect of temperature and air velocity on the drying rate and kinetic of moringa milk powder, and also to determine the nutritional content of moringa milk powder.

\subsection{METHODOLOGY}

\subsection{Moringa Milk Powder Preparation}

Dried moringa leaves were obtained from Moringa Organik Indonesia company, Blora, and sesame seed was purchased from Pasar Gede, Surakarta. The leaves and the seed were crushed using a blender before the next process. The additional ingredients were white eggs and maltodextrin. The white eggs are a foaming agent [13]. The foam mat drying method was chosen because the foam layer that was formed would increase the drying surface area and provide a porous structure to the material, so that heat transfer occurred in all parts causing the evaporation process became faster [14].

Maltodextrin is a foam stabilizer, a filler that can increase the drying rate, used to prevent thermal degradation of the active components of the sample, and used to increase the volume of the sample [15]. This food-grade maltodextrin was bought from Cipta Kimia store, Surakarta.

30 grams moringa leaves, 10 grams sesame seed, and $300 \mathrm{ml}$ water were blended together for ten minutes using a blender. The mixture was filtered by filter paper with $0.2 \mathrm{~mm}$ thickness. The filter cake that was retained on the filter was mixed with $15 \%(\mathrm{w} / \mathrm{w})$ white eggs and $20 \%(\mathrm{w} / \mathrm{W})$ maltodextrin. All of the ingredients were mixed for 7 minutes using a mixer so that the foam was formed. The mixture with $5 \mathrm{~mm}$ thickness was put on stainless steel baking pan. The filled pan was weighed and entered the tray dryer that had been blown with hot air velocity variation and temperature variations of $0.2 \mathrm{~m} / \mathrm{s}$ and $0.3 \mathrm{~m} / \mathrm{s}$, and $90^{\circ} \mathrm{C}, 110^{\circ} \mathrm{C}$, and $130^{\circ} \mathrm{C}$, respectively. Sample was weighed every 20 minutes and the drying process was stopped when the weight of the sample was constant. 


\subsection{Operating Tray Dryer}

Tray dryer that was used in this study can be seen in Figure 1. The first step in operating the tray dryer (1) was turning the blower (9) on. The blower would flow the air to furnace (2). The capacity of the blower was $1 \mathrm{hp}$. The air velocity was the free variable that was controlled by setting the opening of the valve (5). When the valve was opened, changes in pressure drop were shown on the $U$ pipe manometer (8) that had been calibrated. Thermocouples were installed inside the pipe where the air entered, furnace, and chimney. Liquefied petroleum gas (LPG) was used as fuel gas inside the furnace. Burner (3) that had been installed with gas was turned on in the furnace. The air was heated in the furnace, then entered the tray dryer with $30 \mathrm{~cm} \times 30 \mathrm{~cm} \times 40 \mathrm{~cm}$ dimensions. There was heat and mass transfer between hot air and sample in tray dryer. The water vapor carried by the hot air discharged through the chimney.

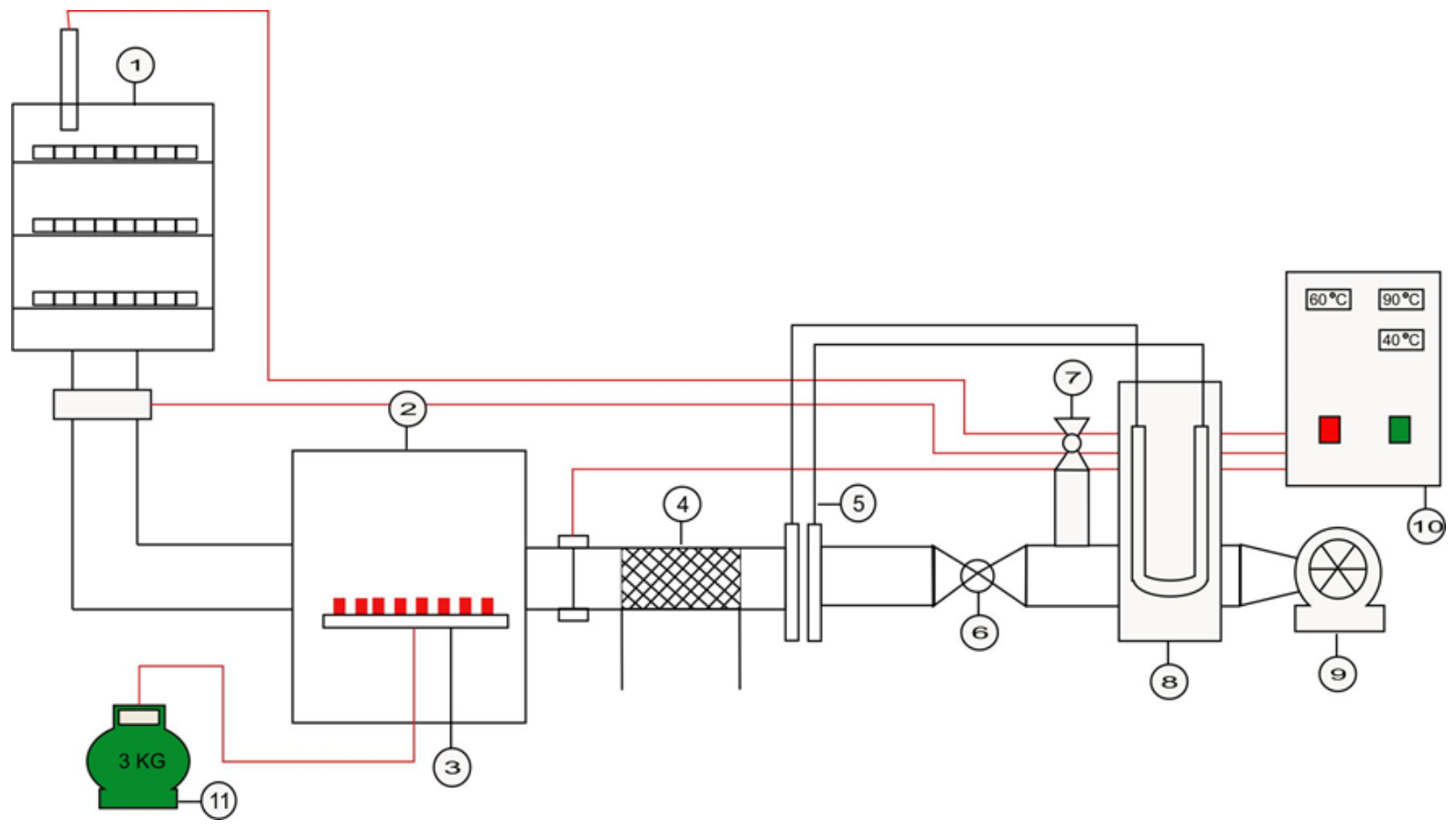

Notation:
1. Tray
4. Dryer
7. Ball Valve
10. Thermo control
2. Furnace
5. Orifice meter
8. U pipe
6. Butterfly valve
9. Blower
11. LPG
3. Burner

Figure 1 Tray Dryer Flow Diagram

In this experiment, the air velocity of $0.2 \mathrm{~m} / \mathrm{s}$ and 0.3 $\mathrm{m} / \mathrm{s}$, and temperatures of $90^{\circ} \mathrm{C}, 110^{\circ} \mathrm{C}$, and $130^{\circ} \mathrm{C}$ were varied to obtain moringa milk powder, and reduced the moisture content of the sample to prevent the sample from microbial growth. Temperature variations up to $130^{\circ} \mathrm{C}$ aimed to determine the effect of temperature on drying time and chemical content of moringa leaf milk powder. A study conducted by Ogrodowska, et al. [16], drying at the temperature of $130{ }^{\circ} \mathrm{C}$ did not damage the bioactive in pumpkin seeds, so that temperature variations up to $130^{\circ} \mathrm{C}$ was still allowed as moringa leaves and sesame seeds are also contain high bioactive content.

\subsection{Drying Rate}

Measurement of moisture content was carried out before and after drying. The moisture content in the material is expressed in percent by the weight of the sample. Moisture content can be defined in terms of wet weight (wet basis) or dry weight (dry basis) which can be calculated by Equations 1 and 2. The moisture content against time data is used to determine the rate of moisture content change $(-d X / d t)$ by determining the slope from the point on the graph. The drying rate is defined by Equation 3 [17]. Drying kinetics using Lewis Model defined in Equation 5.

Moisture content equation

Wet basis $=\frac{W a}{W b+W a} \times 100 \%$

Dry basis $=\frac{W a}{W b} \times 100 \%$

where,

Wa = Weight of water, gram

Wb = Weight of dried sample, gram 
Drying rate equation

$\mathrm{R}=-\frac{L s}{A} \frac{d X}{d t}$

where,

$\mathrm{R} \quad \quad=$ Drying rate, $\mathrm{kg} \mathrm{m}^{-2} \mathrm{~h}^{-1}$

A $\quad$ = Surface area, $\mathrm{m}^{2}$

Ls $\quad=$ Weight of dried sample, gram

$\mathrm{dX} / \mathrm{dt} \quad=$ Change in moisture content

Kinetic drying by Lewis Model

$M R=\frac{M-M_{e}}{M_{\mathrm{i}}-M_{e}}=e^{-\mathrm{ht}}$

From Lim, et al., 2020 [18], Lewis model is linearized in the form of Equation 5

$\ln (M R)=-\mathbb{R} t+\mathbb{1}$

where,

MR = Moisture ratio

$M \quad=$ Moisture content at certain time

$\mathrm{Me} \quad=$ Equilibrium moisture content

$\mathrm{Mi}_{\mathrm{i}} \quad=$ Initial moisture content

$\mathrm{k}=$ Drying kinetic constant $\left(\mathrm{min}^{-1}\right)$

\subsection{Analysis of Moringa Milk Powder}

The results of Moringa milk powder were analyzed for fat and protein content, and its solubility in water. Fat content was analyzed using the Soxhlet method. The solvent used in this method was hexane. Hexane is selective for more hydrophobic lipid, cheaper, and less flammable than ethyl ether [19]. Experiment started with the extraction process. First, installing the extraction equipment, such as boiling flask, mantle heater, extraction flask and condenser. The sample was weighed as much as 1 gram, then put into the extraction flask. Hexane of $250 \mathrm{~mL}$ was put into the extraction flask. Extraction was carried out for approximately 3 hours with a total of 3 times reflux. After the extraction process, the next process was separating the solvent and the extract fat by distillation. The tools used in the distillation process were flasks, mantle heaters, condenser and Erlenmeyer flask. Distillation was stopped when there was no more solvent evaporated. The flask containing the extract fat was put in an oven with the temperature of $105^{\circ} \mathrm{C}$ for 1 hour to remove the remaining solvent, then cooled in a desiccator and weighed. From Nielsen [19], fat content is determined using equation below.

Fat content $=\frac{W_{3}-W_{2}}{W_{1}} \times 100 \%$

where,

$\mathrm{W}_{1} \quad=$ Weight of the sample, gram

$\mathrm{W}_{2} \quad=$ Weight of the flask before extraction process, gram

$\mathrm{W}_{3}=$ Weight of the flask after extraction process, gram
Protein content of moringa milk powder was analyzed in Product Quality Testing and Certification Centre BPSMB laboratory, Surakarta. Kjeldahl method was used to determine the protein contained in moringa milk powder. The solubility of moringa milk powder in water was measured using Total Dissolved Solid (TDS) meter. 5 gram of moringa milk powder were dissolved in $60 \mathrm{~mL}$ hot water, then TDS meter was immersed in the solution. The quantitative result would appear on TDS meter's screen.

\subsection{RESULT AND DISCUSSION}

The moisture content of the material was measured every 20 minutes until the weight of the material reached a constant value. The moisture content of the material was $74 \%$. The research was carried out by varying the operating temperature and the input air velocity. The air in this study had an average relative humidity of $50 \%$. The dried mixture was then crushed and sieved so that the particle size was homogeneous. After drying, the color of the material changed from dark green to brownish green as shown in Figure 2. Chemical and biochemical reactions occur during drying process. These reactions affect the color (browning) of food products. The rate of browning is high at relatively low water content, and this explain the appearance of browning in dried foods [20].

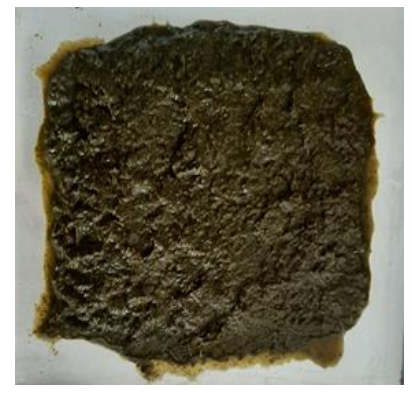

(a)

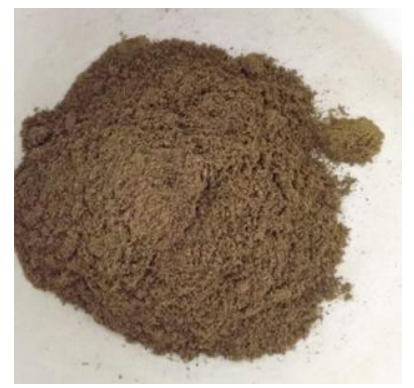

(b)
Figure 2 (a) mixed slurry before drying process (b) moringa milk powder after drying

\subsection{The Effect of Operating Temperature on Drying Time}

The effect of various operating temperature on drying time are shown in Figure 3. It shows that the moisture content of the material decreased until the weight of the material was constant at a certain time. The drying process of the material with a moisture content of $74 \%$ using an air velocity of $0.2 \mathrm{~m} / \mathrm{s}$ required a drying time of 460 minutes at $90^{\circ} \mathrm{C}, 280$ minutes at $110^{\circ} \mathrm{C}$, and 200 minutes at $130^{\circ} \mathrm{C}$.

The results of this study indicate that the higher the operating temperature, the faster the drying time will be. The difference of the temperature causes heat transfer from the air that has a higher temperature to the material that has a lower temperature, so that the 
water in the material was evaporated [21]. The drying process generally causes the nutrients of the material to decrease. According to a research conducted by Clement, et al. [22], it was known that the higher the drying temperature, the fewer nutrients in moringa leaves such as vitamin $A$, vitamin $C$, and protein. However, if the drying is operated at a low temperature, the drying requires a very long drying time. Thus, an optimum temperature is needed so that drying can be carried out in a relatively short time, but it will not reduce the nutrients of the material.

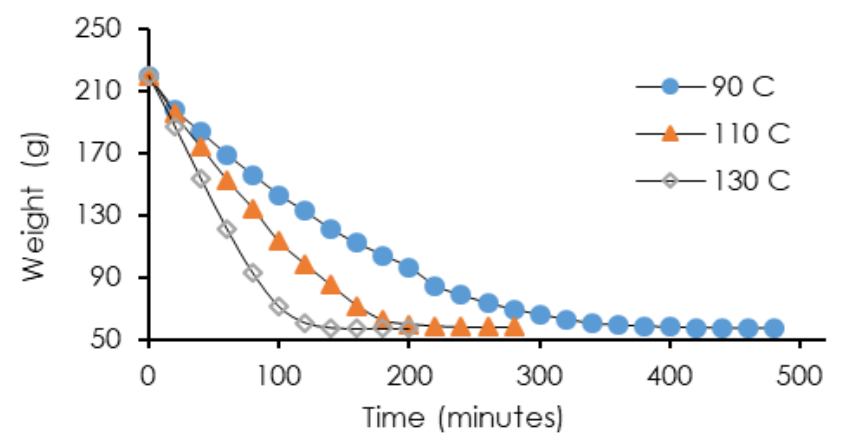

Figure 3 The effect of drying temperature on drying time at the temperature variation of $90^{\circ} \mathrm{C}, 110^{\circ} \mathrm{C}$, and $130^{\circ} \mathrm{C}$

\subsection{The Effect of Air Velocity on Drying Time}

The variations in the input air velocity is presented in Figure 4. The drying time of various temperatures at the air velocity of $0.2 \mathrm{~m} / \mathrm{s}$ was longer than the air velocity of $0.3 \mathrm{~m} / \mathrm{s}$. At the temperature of $90^{\circ} \mathrm{C}$ with air velocity of $0.2 \mathrm{~m} / \mathrm{s}$, the drying time was 480 minutes while for air velocity of $0.3 \mathrm{~m} / \mathrm{s}$ was 400 minutes. At the temperature of $110^{\circ} \mathrm{C}$ with air velocity of $0.2 \mathrm{~m} / \mathrm{s}$, the drying time was 280 minutes while for air velocity $0.3 \mathrm{~m} / \mathrm{s}$ was 260 minutes. At the temperature of $130^{\circ} \mathrm{C}$, for air velocity at $0.2 \mathrm{~m} / \mathrm{s}$, the drying time was 200 minutes while for air velocity $0.3 \mathrm{~m} / \mathrm{s}$ was 180 minutes.

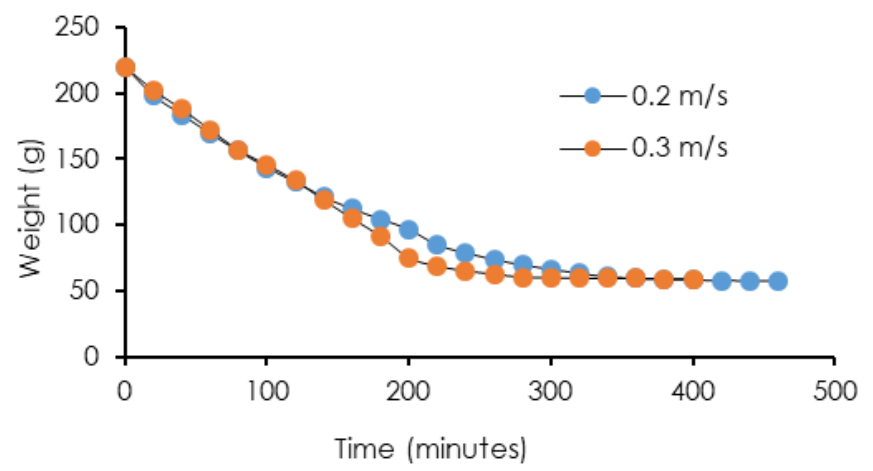

(a)

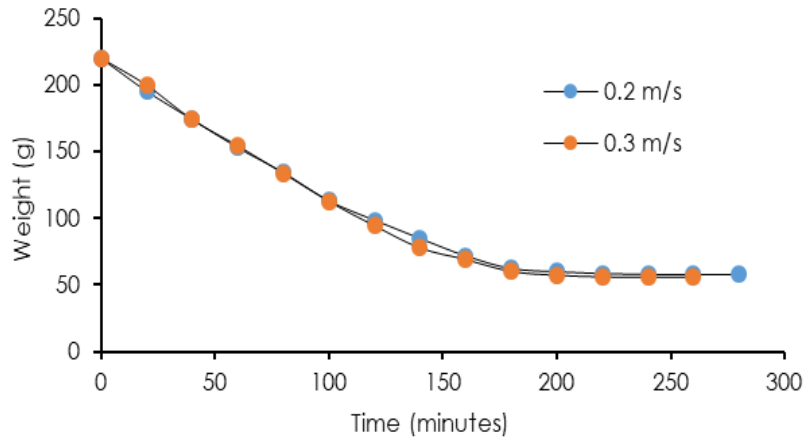

(b)

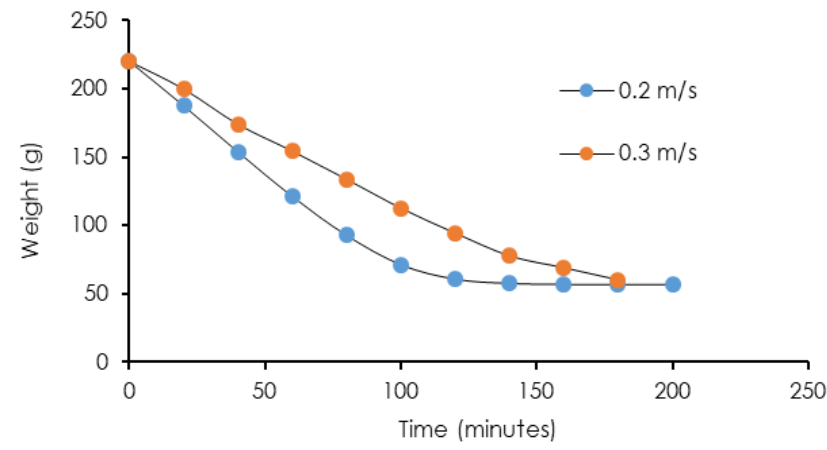

(c)

Figure 4 The effect of air velocity on drying time at (a) $90^{\circ} \mathrm{C}$ (b) $110^{\circ} \mathrm{C}$ (c) $130^{\circ} \mathrm{C}$

From the result of this experiment, it can be concluded that the higher the drying air velocity, the shorter the drying time. This was because the moisture content of the material inside was higher than the moisture content of the surface of the material so that the water inside moved towards the surface, then the heat transfer from the air to the surface of the material caused the water on the surface evaporate [23]. The higher the air velocity, the volume of the air will increase so that the capacity of the air to absorb the water vapor increases [24].

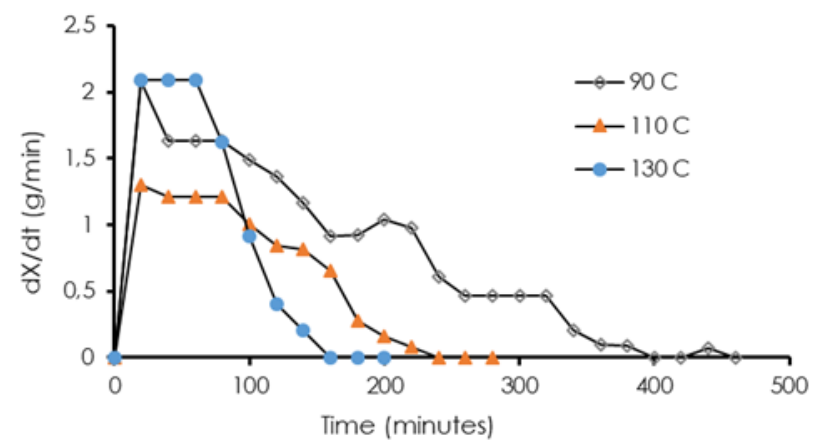

(a) 


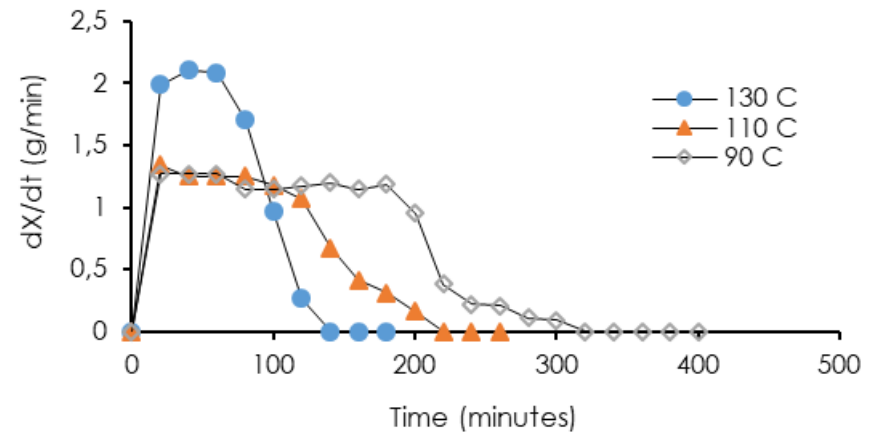

(b)

Figure 5 The effect of drying temperature and air velocity on the changes in moisture content with time (a) at $0.2 \mathrm{~m} / \mathrm{s}(\mathrm{b})$ at $0.3 \mathrm{~m} / \mathrm{s}$

\subsection{The effect of Temperature and Air Velocity on the} Changes in Moisture Content with Time

The moisture content reached a constant value at the shortest time of 180 minutes, when the operating temperature was $130^{\circ} \mathrm{C}$ and air velocity was $0.3 \mathrm{~m} / \mathrm{s}$ as presented in Table 2 and Figure 5. While the moisture content reached a constant value at the longest time of 460 minutes, when the operating temperature was $90^{\circ} \mathrm{C}$ and air velocity was $0.2 \mathrm{~m} / \mathrm{s}$. From these data, it can be concluded that the temperature and air velocity affect the length of the drying time.

Table 2 Drying Time, Moisture Content and dX/dt data

\begin{tabular}{|c|c|c|c|}
\hline $\mathrm{T}\left({ }^{\circ} \mathrm{C}\right)$ & $t$, minutes & $\begin{array}{c}\text { Moisture Content, } \\
\mathrm{X} \\
\end{array}$ & $\begin{array}{c}\text { dX/dt, } \\
\text { g/minute }\end{array}$ \\
\hline \multicolumn{4}{|c|}{ Air velocity: $0.2 \mathrm{~m} / \mathrm{s}$} \\
\hline & 20 & 2.450 & 2.082 \\
\hline \multirow{3}{*}{90} & 80 & 1.716 & 1.636 \\
\hline & 200 & 0.678 & 1.041 \\
\hline & 20 & 2.374 & 1.304 \\
\hline \multirow[t]{3}{*}{110} & 80 & 1.320 & 1.211 \\
\hline & 200 & 0.036 & 0.163 \\
\hline & 20 & 2.304 & 2.089 \\
\hline \multirow[t]{2}{*}{130} & 80 & 0.633 & 1.625 \\
\hline & 200 & 0 & 0 \\
\hline \multicolumn{4}{|c|}{ Air Velocity : $0.3 \mathrm{~m} / \mathrm{s}$} \\
\hline \multirow[t]{3}{*}{90} & 20 & 2.419 & 1.272 \\
\hline & 80 & 1.651 & 1.145 \\
\hline & 200 & 0.267 & 0.953 \\
\hline \multirow[t]{3}{*}{110} & 20 & 2.580 & 1.342 \\
\hline & 80 & 1.397 & 1.246 \\
\hline & 200 & 0.026 & 0.161 \\
\hline \multirow[t]{3}{*}{130} & 20 & 2.495 & 1.992 \\
\hline & 80 & 0.614 & 1.704 \\
\hline & 200 & 0 & 0 \\
\hline
\end{tabular}

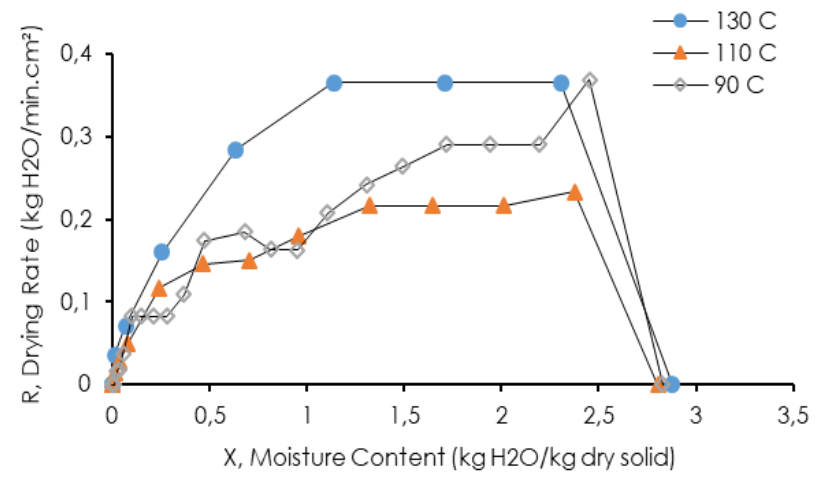

(a)

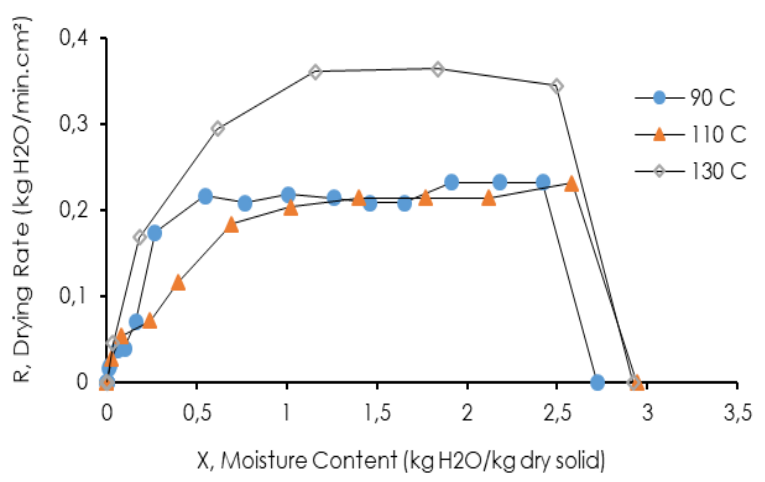

(b)

Figure 6 Effect of drying conditions on constant drying rate (Rc) (a) at $0.2 \mathrm{~m} / \mathrm{s}$ (b) at $0.3 \mathrm{~m} / \mathrm{s}$

3.4 The effect of Operating Temperature and Drying Air Velocity on Critical Time (tc), Critical Moisture Content (Xc) Constant Drying Rate (Rc), and Kinetic Drying (k)

In Table 3 and Figure 6, it was found the values of critical time, critical water content, and critical temperature. The optimum drying process is a process that has the highest value of constant drying rate, Rc [14]. In this study, the optimum constant drying rate was $0.365 \mathrm{~kg} \mathrm{H} 2 \mathrm{O} / \mathrm{min} . \mathrm{cm}^{2}$. This optimum value was found in the drying operation conditions with an air velocity of $0.2 \mathrm{~m} / \mathrm{s}$ and a temperature of $130^{\circ} \mathrm{C}$. This is in line with the drying kinetics based on the Lewis model presented in Table 4. Equation 5 shows the equation suggested by Lewis model. The optimum drying occurs at a temperature of more than $100{ }^{\circ} \mathrm{C}$ because the water content is more volatile, but this is inversely proportional to the air velocity which affects mass transfer. At low air velocities the mass transfer of water to air is more optimal than at high air velocities. This is due to the increasing air velocity causes the air absorb so much water from the surface of the paste so that the dry bulb temperature decreases, then the dry bulb temperature gets closer to the wet bulb temperature, so the wet bulb temperature depression also decreases. This 
causes the ability of the air to absorb water from the surface of the paste is reduced [25].

Table 3 The Result of $t_{c}, X_{c}, R_{c}$

\begin{tabular}{|c|c|c|c|}
\hline $\mathrm{T}\left({ }^{\circ} \mathrm{C}\right)$ & $\begin{array}{c}t_{c} \\
\text { (minutes) }\end{array}$ & $\begin{array}{c}X_{c} \\
\text { (kg H} \mathrm{H}_{2} \mathrm{O} / \mathrm{kg} \text { dry } \\
\text { solid) }\end{array}$ & $\begin{array}{c}R_{c} \\
\left(\mathrm{~kg} \mathrm{H} \mathrm{H}_{2} \mathrm{O} /\right. \\
\left.\text { min. } \mathrm{cm}^{2}\right)\end{array}$ \\
\hline \multicolumn{4}{|c|}{ Air Velocity: $0.2 \mathrm{~m} / \mathrm{s}$} \\
\hline 90 & 40 & 2.196 & 0.290 \\
\hline 110 & 40 & 2.008 & 0.216 \\
\hline 130 & 20 & 2.304 & 0.365 \\
\hline \multicolumn{4}{|c|}{ Air Velocity: $0.3 \mathrm{~m} / \mathrm{s}$} \\
\hline 90 & 20 & 2.419 & 0.232 \\
\hline 110 & 40 & 2.118 & 0.214 \\
\hline 130 & 20 & 2.495 & 0.344 \\
\hline
\end{tabular}

Table 4 Drying kinetic $k$

\begin{tabular}{|c|c|c|}
\hline $\mathrm{T}\left({ }^{\circ} \mathrm{C}\right)$ & $\begin{array}{c}k \\
\left(\min ^{-1}\right)\end{array}$ & $R^{2}$ \\
\hline \multicolumn{3}{|c|}{ Air Velocity: $0.2 \mathrm{~m} / \mathrm{s}$} \\
\hline 90 & 0.0121 & 0.885 \\
\hline 110 & 0.0210 & 0.867 \\
\hline 130 & 0.0335 & 0.898 \\
\hline \multicolumn{3}{|c|}{ Air Velocity: $0.3 \mathrm{~m} / \mathrm{s}$} \\
\hline 90 & 0.0161 & 0.920 \\
\hline 110 & 0.0167 & 0.891 \\
\hline 130 & 0.0271 & 0.876 \\
\hline
\end{tabular}

\subsection{Fat Content}

The fat content of moringa milk powder was compared with the Indonesian National Standard. SNI 01-29702006 was the Indonesian standard used to evaluate the fat content of the moringa milk powder whether the product met the standard, so that it can be produced in large quantities and can be consumed. Table 5 shows that the fat content values for all temperature variations of $90^{\circ} \mathrm{C}, 110^{\circ} \mathrm{C}$, and $130^{\circ} \mathrm{C}$ have met the minimum standard. The fat content of $14 \%$ was the highest value that was obtained by operating the dryer at the drying temperature of $110^{\circ} \mathrm{C}$ and air velocity of $0.2 \mathrm{~m} / \mathrm{s}$.

Table 5 Results of Fat Content Analysis

\begin{tabular}{cccc}
\hline $\begin{array}{c}\text { Air } \\
\text { Velocity } \\
(\mathbf{m} / \mathbf{s})\end{array}$ & $\begin{array}{c}\text { Drying } \\
\text { Temperature( } \\
\text { C) }\end{array}$ & $\begin{array}{c}\text { Fat } \\
\text { Content } \\
\mathbf{( \% )}\end{array}$ & $\begin{array}{c}\text { Fat Content } \\
\mathbf{1 , 5 \%}<\mathbf{x}<\mathbf{2 6 \%}\end{array}$ \\
\hline \multirow{2}{*}{0.2} & 90 & 4 & Accepted \\
& 110 & 14 & Accepted \\
& 130 & 12 & Accepted \\
& 90 & 12 & Accepted \\
0.3 & 110 & 10 & Accepted \\
& 130 & 10 & Accepted \\
\hline
\end{tabular}

\subsection{Protein Content}

The protein content contained in the moringa milk powder is presented in Table 6. This experiment was carried out using the Kjeldahl method. From the results, it was found that increasing drying temperature would increase the protein content of the moringa milk powder. In general, if the operating temperature is high, it will cause the denaturation of the material, for the example, the study conducted by Anandharamakrishnan et al. [26] showed that the optimum temperature to avoid the denaturation of the protein of whey was at the temperature of $60-80^{\circ} \mathrm{C}$. However, in this study, it was found that the protein content of the material increased linearly with temperature. During the drying process, which was about 160-440 minutes, the nutrients content of the material, such as vitamin $A$ and vitamin $C$, were defective and decreased the mass weight of the powder so that the total protein percentage increased.

Table 6 The Result of Protein Test

\begin{tabular}{ccc}
\hline $\begin{array}{c}\text { Air } \\
\text { Velocity } \\
(\mathrm{m} / \mathrm{s})\end{array}$ & $\begin{array}{c}\text { Drying } \\
\text { Temperature } \\
\left({ }^{\circ} \mathrm{C}\right)\end{array}$ & $\begin{array}{c}\text { Protein } \\
\mathbf{( \% )}\end{array}$ \\
\hline \multirow{2}{*}{0.3} & 90 & 18.81 \\
& 110 & 19.00 \\
& 130 & 19.20 \\
\hline
\end{tabular}

\subsection{Solubility in Water}

The results of the solubility test of moringa milk powder is presented Table 7. From the solubility data obtained, it can be seen that variations in drying temperature and air velocity affect drying.

The higher the drying temperature, the more the powder was dissolved in water. The difference of air velocity also had an effect on the dissolved powder concentration value. The dissolved powder concentration at the air velocity of $0.3 \mathrm{~m} / \mathrm{s}$ was higher than the dissolved powder concentration at the air velocity of $0.2 \mathrm{~m} / \mathrm{s}$.

Table 7 The Result of Total Dissolved Solids

\begin{tabular}{cccc}
\hline $\begin{array}{c}\text { Air } \\
\text { Velocity } \\
(\mathbf{m} / \mathbf{s})\end{array}$ & $\begin{array}{c}\text { Drying } \\
\text { Temperature } \\
\left({ }^{\circ} \mathbf{C}\right)\end{array}$ & $\begin{array}{c}\text { Total Dissolved } \\
\text { Solids } \\
(\mathbf{p p m})\end{array}$ & $\begin{array}{c}\text { Solubility } \\
\mathbf{( \% )}\end{array}$ \\
\hline \multirow{2}{*}{0.2} & 90 & 1004 & 1.2048 \\
& 110 & 1035 & 1.2424 \\
& 130 & 1180 & 1.416 \\
0.3 & 90 & 1080 & 1.296 \\
& 110 & 1130 & 1.356 \\
& 130 & 1630 & 1.956 \\
\hline
\end{tabular}




\subsection{Physical Changes}

The physical change of moringa milk powder without the addition of any preservative material had observed for more than 3 months. It can be seen from Figure 7 (a) showing moringa milk powder after drying and (b) after 3 months. It shows that there is no significant differences.

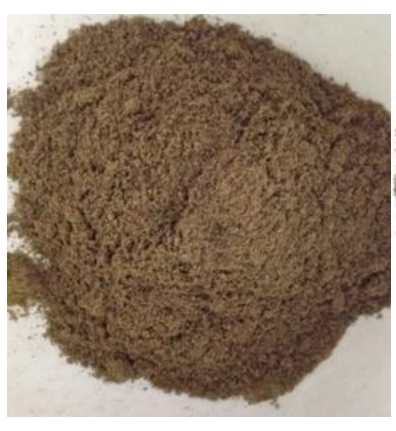

(a)

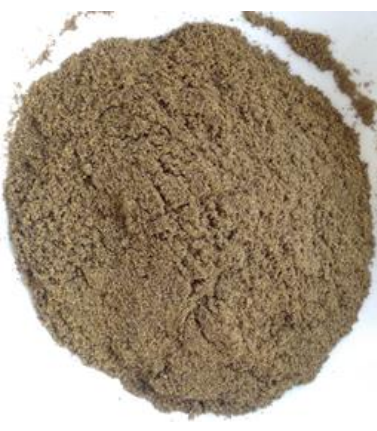

(b)
Figure 7 Moringa milk powder: (a) after drying process (b) after more than 3 months

\subsection{CONCLUSION}

This research studies the effect of temperature and air velocity on the drying rate and drying kinetics of Moringa leaf milk powder on the tray dryer. Moringa paste drying time is shorter at high temperature and low air velocity. The optimum drying conditions were obtained at a temperature of $130 \mathrm{C}$ and an air velocity of $0.2 \mathrm{~m} / \mathrm{s}$ with a dying rate Rc of $0.365 \mathrm{~kg} \mathrm{H} \mathrm{H}_{2} \mathrm{O} / \mathrm{min} . \mathrm{cm}^{2}$ and a kinetic drying constant $\mathrm{k}$ of $0.0335 \mathrm{~min}^{-1}$ based on the Lewis model.

The highest fat content was $14 \%$ for the drying temperature of $110^{\circ} \mathrm{C}$ and an air velocity of $0.2 \mathrm{~m} / \mathrm{s}$. All samples tested met the Indonesian National Standard (SNI) for milk powder. However, from fat content analysis data, there was no data trend that showed the effect of drying temperature and air velocity variation on fat content of moringa milk powder. The protein analysis showed that increasing drying temperature of moringa leaves increased the protein content of the moringa milk powder, the highest protein content was $19,2 \%$ for the drying temperature of $130^{\circ} \mathrm{C}$ and air velocity of $0.3 \mathrm{~m} / \mathrm{s}$. Meanwhile, in the solubility test showed that the higher the drying temperature, the greater the amount of moringa milk powder dissolved, however, the solubility percentage of moringa milk powder was still very small. The highest solubility percentage is $1.956 \%$ at the drying temperature of $130^{\circ} \mathrm{C}$ and air velocity of $0.3 \mathrm{~m} / \mathrm{s}$.

\section{Acknowledgement}

This work was supported by Capacity Building Research Group LPPM Universitas Sebelas Maret, Surakarta, Indonesia.

\section{References}

[1] Kementrian Pertanian. 2019. Buku Outlook Komoditas Peternakan Susu Sapi. Pusat Data dan Sistem Informasi Pertanian.

[2] Fiocchi, A., Brozek, J., Schünemann, H., and Bozzola, M. 2010. World Allergy Organization (WAO) Diagnosis and Rationale for Action Against Cow's Milk Allergy (DRACMA) Guidelines. World Allergy Organization Journal. 3(4): 57-161.

[3] Vergara-Jimenez, M., Almatrafi, M. M., and Fernandez, M. L. 2017. Bioactive Components in Moringa Oleifera Leaves Protect Against Chronic Disease. Antioxidants. 6(4): 1-13.

[4] Anggorowati, D.A., Minah, F.N., Harimbi, S., and Sriliani, S. 2018. Moringa Leaf Potential (Moringa oleifera) for the Manufacture of Instant Drink Powder with Variations in Tween 80 Volume and Drying Temperature as an Antioxidant Drink. International Journal of ChemTech Research. 11(5): 295-300.

[5] Hedhili, A., Lubbers, S., Bou-Maroun, E., Griffon, F., Akinyemi, B. E., Husson, F., and Valentin, D. 2021. Moringa Oleifera Supplemented Biscuits: Nutritional Values and Consumer Segmentation. South African Journal of Botany. 138: 406-414.

[6] Ali, M. A., Yusof, Y. A., Chin, N. L., and Ibrahim, M. N. 2017. Processing of Moringa Leaves as Natural Source of Nutrients by Optimization of Drying and Grinding Mechanism. Journal of Food Process Engineering. 40(6): el2583. DOI: https://doi.org/10.1111/jfpe.12583.

[7] Dravie, E. E., Kortei, N. K., Essuman, E. K., Tettey, C. O., Boakye, A. A., and Hunkpe, G. 2020. Antioxidant, Phytochemical and Physicochemical Properties of Sesame Seed (Sesamum indicum L). Scientific African. 8: e00349. DOI: https://doi.org/10.1016/j.sciaf.2020.e00349.

[8] U.S. Department of Agriculture. 2020. Agricultural Research Service, Food Data Central.

[9] Fontana, A. J. 2000. Understanding the Importance of Water Activity in Food. Cereal Foods World. 45(1): 7-10.

[10] Waluyo, J., Prasetyaningsih, Y., Sari, M.W., and Ekawandani, N. 2019. The Drying Rate of Mushroom on Tray Dryer and Effect of Mushroom Powder on Organoleptic Properties of Batagor. IOP Conference Series: Materials Science and Engineering. 633012045.

[11] Guda, P., and Gadhe, S. 2017. Drying of Cocoa Beans by Using Different Techniques. International Journal of Agriculture Innovations and Research. 5(5): 859-864.

[12] Naik, V., Krishi Vidyapeeth, M., Shere, I., Pd, S., Surendar, J., and Dm, S. 2018. Effect of Drying on Quality Characteristics of Dried Tomato Powder. Journal of Pharmacognosy and Phytochemistry. 7(2): 2690-2694.

[13] Hossain, M. A., Mitra, S., Belal, M., and Zaman, W. 2021. Effect of Foaming Agent Concentration and Drying Temperature on Biochemical Properties of Foam Mat Dried Tomato Powder. Food Research. 5(1): 291-297. DOI: https://doi.org/10.26656/fr.2017.5(1).372.

[14] Hariyadi, T. 2018. Pengaruh Suhu Operasi terhadap Penentuan Karakteristik Pengeringan Busa Sari Buah Tomat Menggunakan Tray Dryer. Jurnal Rekayasa Proses. 12(2): 4655.

[15] Kurniasari, F., Hartati, I., and Kurniasari, L. 2019. Aplikasi Metode Foam Mat Drying pada Pembuatan Bubuk Jahe (Zingiber officinale). Jurnal Inovasi Teknik Kimia. 4(1): 7-10.

[16] Ogrodowska, D., Tanska, M., Brandt, W. 2017. The Influence of Drying Process Conditions on the Physical Properties, Bioactive Compounds and Stability of Encapsulated Pumpkin Seed Oil. Food and Bioprocess Technology. 10: 1265-1280

[17] Geankoplis, C. J. 1993. Transport Processes and Unit Operations. Prentice-Hall International: New Jersey, USA.

[18] Lim, G. W., Jafarzadeh, S. and Norazatul, M. R. 2020. Kinetic Study, Optimization and Comparison of Sun Drying $D$ Superheated Steam Drying of Asam Gelugor (Garcinia cambogia). Food Research. 4(2): 396-406. DOI: https://doi.org/10.26656/fr.2017.4(2).288.

[19] Nielsen, S. S. 2017. Food Analysis. Springer International: West Lafayette, IN, USA. 
[20] Tsotsas, E., and Mujumdar, A. S. 2017. Modern Drying Technology Volume 3: Product Quality and Formulation. Wiley-VCH Verlag: Weinheim, Germany.

[21] labal M, J., Akbar M, W., Aftab, R., Younas, I., and Jamil, U. 2019. Heat and Mass Transfer Modeling for Fruit Drying: a Review. MOJ Food Processing \& Technology. 7(3): 69-73.

[22] Clement, A., Olatunde, M., Patrick, O., and Joyce, O. 2017. Effect of Drying Temperature on the Nutritional Quality of Moringa Oleifera Leaves. World Journal of Food Science and Technology. 9(1): 93-96.

[23] Simpson, W. T. 1997. Effect of Air Velocity on the Drying Rate of Single Eastern White Pine Boards. Research Note Forest Products Laboratory, U.S. Department of Agriculture Forest
Service. 5 pp.

[24] Putra, R. N., and Ajiwiguna, T. A. 2017. Influence of Air Temperature and Velocity for Drying Process. Procedia Engineering. 170 :

516-519. DOl: http://dx.doi.org/10.1016/j.proeng.2017.03.082.

[25] Carter, Lyle. 1990. Should Air Velocity be Increased or Decreased. Proc. of the 41 st Meeting of the Western Dry Kiln Assoc. (Western Dry Kiln Association, Oregon State University). 79-83

[26] Anandharamakrishnan, C., Rielly, C. D., and Stapley, A. G. F. Effects of Process Variables on the Denaturation of Whey Proteins during Spray Drying. Drying Technology. 25: 799-807. DOI: https://doi.org/10.1080/07373930701370175. 